\title{
FAKTOR YANG BERHUBUNGAN DENGAN INTENSI MASYARAKAT UNTUK BEROBAT KE PELAYANAN KESEHATAN
}

\author{
Penta Luis Sandi ${ }^{1}$, Cicilia Nony Ayuningsih Bratajaya ${ }^{2}$, \\ Wilhelmus Hary Susilo ${ }^{3}$ \\ 1,2Sekolah Tinggi IlmuKesehatan Sint Carolus, Jl. Salemba Raya No. 41 Jakarta Pusat \\ 3Universitas Persada Indonesia YAI, Jl. Pangeran Diponegoro No. 74 Jakarta Pusat \\ Email: cicilia.bratajaya@gmail.com
}

\begin{abstract}
ABSTRAK
Intensi atau niat berkunjung ke Puskesmas Pembantu merupakan keinginan untuk datang berobat ke Pelayanan Kesehatan. Beberapa kendala dialami masyarakat untuk pergi ke pelayanan kesehatan. Theory of Planned Behavior (TPB) digunakan untuk memprediksi niat seseorang memanfaatkan fasilitas kesehatan yang dapat didasari oleh kesadaran untuk datang ke fasilitas kesehatan, dukungan keluarga, dan situasi yang dirasakan. Tujuan penelitian ini untuk mengetahui faktor-faktor yang berhubungan dengan intensi masyarakat di salah satu RW Desa Kota baru Kecamatan Padangratu Kabupaten Lampung Tengah untuk berobat Ke Puskemas Pembantu Kotabaru dengan menggunakan pendekatan TPB. Penelitian ini menggunakan metode kuantitatif dengan pendekatan Cross Sectional. Jumlah populasi kepala keluarga (KK) di salah satu RW sebanyak 257 KK. Jumlah sampel sebanyak 155 KK yang terbagi dalam 4 RT. Data dikumpulkan dengan teknik Stratified Random Sampling. Pengumpulan data dengan menggunakan kuesioner dan data dianalisis menggunakan uji Kendall Tau b. Hasil dari penelitian menerangkan bahwa sikap berhubungan dengan intensi ( $p$-Value 0,010$)$, norma subyektif berhubungan dengan intensi ( $p$-Value $0,000)$, dan control perilaku yang dirasakan tidak berhubungan dengan intensi ( $p$-Value 0,802$)$. Kesimpulan, sikap untuk mau memanfaatkan fasilitas kesehatan dan dukungan orang terdekat menjadi kunci utama untuk meningkatkan intensi atau niat seseorang dalam memanfaatkan fasilitas kesehatan.
\end{abstract}

Kata kunci: sikap; norma subyektif; kontrol perilaku yang dirasakan; Intensi berobat, Pelayanan Kesehatan.

\section{THE RELATED FACTORS TO COMMUNITY INTENTIONS FOR HAVING TREATMENT OF HEALTH SERVICES}

\begin{abstract}
The intention to visit the Public Health Center is the desire for visiting the health service. Several problems experienced by the community for visiting Public Health Center. Theory of Planned Behavior was used to predict the intention of the community to treat their health in Public Health Center. The purpose of this study was to determine related factors to the intention for visiting Public Health Center. This study used a quantitative method with a Cross Sectional approach. The populations were 257 families at Kota Baru urban village. The numbers of 155 families in one of neighbourhood at Kota Baru urban village were recruited by using stratified random sampling into 4 hamlets. Data collection used questionnaires and the data were analyzed by Kendall Tau $b$. The results of the study explain that attitudes were related to intention $(\rho$-Value 0,010$)$, subjective norms are related to intention $(\rho$-Value 0,000$)$ and perceived behaviour control is not related to intention ( $\rho$-Value 0,802$)$. In conclussion, the attitude of community to check their health in public health centre and subjective norms are the key of success to increase community intention to visit health centre.
\end{abstract}

Keywords: attitudes; subjective norms; behaviour control; intention; public health center 


\section{LATAR BELAKANG}

Kesehatan merupakan kebutuhan yang diperlukan oleh setiap orang, baik anak-anak sampai dengan lanjut usia. WHO (2017) menyebutkan ada setengah dari penduduk dunia belum mendapat pelayanan kesehatan primer. Hal tersebut membuat seluruh negara anggota PBB sepakat untuk mencapai cakupan kesehatan universal (Universal Health Coverage/ UHC) pada tahun 2030. BPJS merupakan bentuk upaya mencapai UHC di Indonesia.

Di Indonesia, berdasarkan Permenkes RI No 75 tahun 2014, Puskesmas merupakan faskes pertama yang mengupayakan tindakan promotif dan preventif. Pemerintah terus meningkatkan jumlah dan kualitas layanan Puskesmas dalam upaya menyehatkan masyarakat. Hadirnya pelayanan kesehatan yang disediakan oleh pemerintah harus dimanfaatkan sebaik mungkin oleh masyarakat. Puskesmas merupakan salah satu fasilitas kesehatan tingkat pertama yang dimiliki Indonesia yang perannya sangat penting dalam sistem kesehatan nasional (Kemenkes RI, 2014).

Kecamatan Padangratu, Kabupaten Lampung Tengah, Provinsi Lampung memiliki 2 Puskesmas induk yaitu Puskesmas Padangratu dan Puskesmas Surabaya. Puskesmas Padangratu memiliki 2 Puskesmas Pembantu (Pustu) yaitu Pustu Kotabaru dan Pustu Tugumulyo. Menurut petugas Pustu Kotabaru, sepanjang tahun 20152017 dapat melayani kurang lebih 300 pasien setiap bulannya atau sekitar 10\% dari jumlah penduduk Kotabaru. Pasien yang datang bukan dari Desa Kotabaru saja melainkan ada beberapa desa yang warganya datang untuk berobat. Sementara berdasarkan data kependudukan Kelurahan Kota Baru, jumlah penduduk Desa Kotabaru berkisar 3277 jiwa (Kelurahan Kotabaru, 2017).

Intensi atau niat berkunjung ke Puskesmas Pembantu merupakan keinginan untuk memanfaatkan fasilitas kesehatan dengan datang berobat ke Pelayanan Kesehatan. Namun, beberapa kendala dialami masyarakat untuk pergi ke pelayanan kesehatan. Theory of Planned
Behavior (TPB) digunakan untuk memprediksi intensi masyarakat berobat berdasarkan sikap yang mendasari seseorang untuk memanfaatkan fasilitas kesehatan, dukungan orang terdekat atau norma subjektif, dan kondisi yang mempersulit untuk berobat atau control perilaku yang dirasakan. Ketiga variabel ini dianggap sesuai dengan fenomena yang terjadi pada lokasi penelitian.

TPB merupakan teori yang dikembangkan sejak tahun 1975 hingga saat ini oleh Icek Ajzen seorang psikologi sosial. Teori ini membagi 3 variabel pembentuk intense diantaranya sikap, norma subjektif, dan kontrol perilaku yang dirasakan. Penelitian yang dilakukan oleh Sulistiyani \& Vallen (2015) menerangkan bahwa ada hubungan antara sikap, norma subjektif, dan pengendalian perilaku dengan intensi keluarga berobat ke pelayanan kesehatan tingkat pertama.

Beberapa penelitian dilakukan terkait dengan pengaruh pemanfaatan pelayanan kesehatan diantaranya yaitu Masita et al. (2016) menyebutkan ada hubungan antara akses, kepemilikan asuransi dengan pemanfaatan pelayanan kesehatan dan tidak ada hubungan antara keyakinan terhadap pelayanan kesehatan dengan pemanfaatan pelayanan kesehatan. Napirah et al. (2016) menyebutkan bahwa persepsi masyarakat tentang kesehatan, pendapatan keluarga, tingkat pendidikan berhubungan dengan pemanfaatan pelayanan kesehatan dan persepsi tentang kualitas pelayanan tidak memiliki hubungan. Wulandari et al. (2016) menyebutkan bahwa sarana, sikap petugas kesehatan, dan kesadaran masyarakat memiliki hubungan dalam pemanfaatan pelayanan kesehatan. Sulistiyani \& Vallen (2015) menyebutkan bahwa ada pengaruh bersama-sama antara sikap, norma subjektif dan pengendalian perilaku terhadap intensi keluarga dalam memanfaatkan pelayanan kesehatan.

Peneliti mengadopsi Theory of Planned Behavior (TPB) sebagai dasar penelitian ini, teori ini memiliki 3 variabel kunci pembentuk intensi yaitu sikap, norma subjektif dan control perilaku yang dirasakan. Teori yang dikembangkan oleh Fishbein \& Ajzen (1975) menyatakan perilaku dapat dibentuk dari niat yang muncul dalam diri seorang 
individu (Pender et al., 2011). Niat seseorang untuk melakukan suatu aktivitas didasari oleh sikap seseorang. Variabel sikap adalah ketika seseorang merasa aktivitas yang dilakukannya menguntungkan bagi dirinya maka sikap yang dihasilkan adalah positif dan sebaliknya. Selain sikap, variabel pembentuk yang kedua adalah norma subjektif yaitu dukungan, harapan, atau motivasi dari orang terdekat yaitu keluarga, kerabat, orang sekitar, dan petugas kesehatan. Dukungan dari orang terdekat membuat seseorang menjadi lebih termotivasi untuk melakukan aktivitas. Ketiga, kontrol persepsi yang dirasakan yaitu persepsi yang dirasakan seseorang terhadap suatu situasi atau kondisi yang dihadapinya dalam melakukan aktivitas yang dalam penelitian ini aktivitas tersebut adalah memanfaatkan layanan kesehatan untuk memeriksa kesehatan saat seseorang mengalami masalah kesehatan.

Berdasarkan hasil observasi dan wawancara singkat dengan beberapa warga desa Kotabaru dan petugas Puskesmas sebelum peneliti melakukan penelitian, ada beberapa hal yang menghambat warga untuk datang ke puskemas yaitu alasan keamanan, jarak, tidak adanya dana untuk perjalanan dan transportasi. Puskesmas Padangratu telah menyediakan Puskesmas Pembantu (Pustu) di Kotabaru. Tingkat kunjungan menurut kepala Pustu Kotabaru cukup baik. Namun hasil wawancara singkat dengan beberapa warga mengatakan belum pernah ke Pustu dengan alasan cukup dengan membeli obat warung.

Berdasarkan latar belakang masalah, maka penelitian ini bertujuan untuk mengetahui faktorfaktor yang berhubungan dengan intensi masyarakat untuk berobat ke Puskesmas Pembantu Kotabaru.

\section{METODE}

Penelitian ini menggunakan metode penelitian kuantitatif dengan menggunakan desain korelasi deskriptif dan metode cross sectional (Polit \& Beck, 2012). Pemilihan desain ini bertujuan untuk mengetahui korelasi antara 3 (tiga) variable independent yaitu sikap, norma normatif dan kontrol perilaku yang dirasakan terhadap variabel dependent yaitu intensi.

Populasi dalam penelitian ini adalah kepala keluarga yang ada di salah satu RW di Desa Kotabaru yang berjumlah 257 Kepala Keluarga (KK). Hasil perhitungan sampel dengan table Krecjie dan Morgan (1970) dalam Nasir, Abd. Murith, Abdul. Deputri (2011) sampel yang diambil sebesar $155 \mathrm{KK}$.

Teknik pengambilan sampel pada penelitian ini menggunakan teknik Stratified Random Sampling. Menurut Hasmi (2016) teknik pengambilan sampel ini meningkatkan keterwakilan dan menjangkau variasi sub kelompok. Variasi tiap kelompok diklasifikasikan berdasarkan jenis perkerjaan KK yang terdiri atas petani, wiraswasta, pegawai negeri sipil, dan lain-lain. Pengambilan sampel pada salah satu RW yang terdiri dari 4 RT dihitung berdasarkan proporsi masing-masing RT yaitu berjumlah 45 KK di RT 01, 42 KK di RT 02, 28 KK di RT 03, dan 40 KK di RT 04. Pengacakan sampel dilakukan melalui metode Randbeetwen pada Microsoft Excel setelah memasukan nama KK dan jenis pekerjaan KK. Alat pengumpulan data yang digunakan adalah kuesioner yang dibagikan kepada KK di RW 02. Sebelum dibagikan, kuesioner terlebih dahulu dilakukan uji validitas dan reliabialitas dengan nilai cronbach's alpha untuk 13 pernyataan sikap adalah $0,874,13$ pernyataan norm subjektif adalah 0,9,12 pernyataan kontrol perilaku yang dirasakan adalah 0,839 , dan 10 pernyataan intensi adalah 0,882 .

Data yang sudah terkumpul ,diolah dengan menganalisa data univariat yang menghasilkan distribusi frekuensi dan persentase, selain itu analisa data bivariat dilakukan untuk mengetahui hubungan antar variabel data dianalisa melalui uji Kendall Tau b.

\section{HASIL}

Gambaran karakteristik responden penelitian pada studi ini meliputi usia, jenis kelamin, tingkat pendidikan, pekerjaan, dan jumlah pendapatan rata-rata penduduk setempat. Penelitian ini 
melibatkan 155 responden di salah satu RW di Desa Kotabaru.

\begin{tabular}{lcc}
\multicolumn{3}{l}{ Tabel 1. Karakteristik Responden (n=155) } \\
\hline \multicolumn{1}{c}{ Karakteristik } & $n$ & $\%$ \\
\hline Usia & & \\
20-40 tahun & 45 & 29,0 \\
$41-60$ tahun & 78 & 50,3 \\
$61-80$ tahun & 28 & 18,1 \\
>81 tahun & 4 & 2,6 \\
\hline Jenis Kelamin & & \\
Laki-laki & 146 & 94,2 \\
Perempuan & 9 & 5,8 \\
\hline Pendidikan & & \\
SD & 86 & 55,5 \\
SMP & 39 & 25,2 \\
SMA & 15 & 9,7 \\
Sarjana & 2 & 1,3 \\
Tidak sekolah & 13 & 8,4 \\
\hline Pekerjaan & & \\
Petani & 133 & 85,8 \\
PNS & 1 & 0,6 \\
Wiraswasta & 20 & 12,9 \\
Lain-lain & 1 & 0,6 \\
\hline Pendapatan & & \\
$<2.083 .000$ & 134 & 86,5 \\
>2.083.000 & 21 & 13,5 \\
\hline & & \\
\hline & & \\
\hline & &
\end{tabular}

Pada karakteristik responden (Tabel 1), hasil penelitian menunjukkan bahwa sebagian besar responden berusia antara 41-60 tahun (50,3\%) dan hampir seluruh responden berjenis kelamin laki-laki (94,2\%). Rata-rata pendidikan yang dimiliki oleh responden yaitu SD $(55,5 \%)$. Hampir seluruhnya merupakan petani( $(85,8 \%)$ dengan pendapatan dibawah standard Upah Minimum Kabupaten (UMK) Lampung Tengah tahun 2018 yaitu sebesar Rp 2.083.000 (86,5\%).
Tabel 2. sikap, norma subyektif, kontrol perilaku yang dirasakan, dan intensi

\begin{tabular}{|c|c|c|}
\hline \multicolumn{3}{|c|}{$(\mathrm{N}=155)$} \\
\hline Karakteristik & $n$ & $\%$ \\
\hline \multicolumn{3}{|c|}{ Sikap } \\
\hline Positif & 94 & 60,6 \\
\hline Negatif & 61 & 39,4 \\
\hline \multicolumn{3}{|c|}{ Norma subyektif } \\
\hline Setuju & 93 & 60,0 \\
\hline TidakSetuju & 62 & 40,0 \\
\hline \multicolumn{3}{|c|}{ Kontrol Perilaku yang dirasakan } \\
\hline Didukung & 106 & 68,4 \\
\hline Dihambat & 49 & 31,6 \\
\hline \multicolumn{3}{|c|}{ Intensi masyarakat untuk berobat } \\
\hline Memiliki niat & 119 & 76,8 \\
\hline Tidak niat & 36 & 23,2 \\
\hline
\end{tabular}

Pada variabel pendukung intensi masyarakat untuk berobat ke Puskesmas Pembantu Kotabaru (Tabel 2), hasil penelitian menunjukkan sebagian besar responden memiliki sikap positif terhadap keinginan berobat ketika sakit ke Puskesmas Pembantu $(60,6 \%)$. Dari distribusi frekuensi variable norma subyektif, dapat dilihat sebagian besar responden mendapat dukungan keluarga dalam memanfaatkan pelayanan kesehatan di Puskesmas Pembantu (60\%). Pada distribusi frekuensi control perilaku yang dirasakan, sebanyak 68,4\% responden menyatakan didukung atau tidak ada hambatan yang berarti untuk berobat ke Pusekesmas Pembantu, namun31,6\%) menyatakan masih memiliki hambatan untuk berobat ke Puskesmas Pembantu. 
Tabel 3. Hubungan antara sikap, norma subyektif, kontrol perilaku yang dirasakan dengan intense

\begin{tabular}{|c|c|c|c|c|c|c|c|}
\hline \multicolumn{8}{|c|}{ Intensi } \\
\hline \multirow[t]{2}{*}{ Var. } & \multicolumn{2}{|c|}{ Niat } & \multicolumn{2}{|c|}{$\begin{array}{c}\text { Tidak } \\
\text { Niat }\end{array}$} & \multicolumn{2}{|c|}{ Total } & \multirow[t]{2}{*}{$\begin{array}{c}\rho- \\
\text { Value }\end{array}$} \\
\hline & $\mathrm{n}$ & $\%$ & $\mathrm{n}$ & $\%$ & $\mathrm{n}$ & $\%$ & \\
\hline \multicolumn{8}{|l|}{ Sikap } \\
\hline Positif & 79 & 84,0 & 15 & 16,0 & 94 & 100 & 0,010 \\
\hline Negatif & 40 & 65,6 & 21 & 34,4 & 61 & 100 & \\
\hline \multicolumn{8}{|c|}{ Norma Subyektif } \\
\hline Setuju & & 87,1 & 12 & 12,9 & 93 & 100 & 0,000 \\
\hline Tidak & 38 & 61,3 & 24 & 38,7 & 62 & 100 & \\
\hline Setuju & & & & & & & \\
\hline \multicolumn{8}{|c|}{ Kontrol Perilaku yang Dirasakan } \\
\hline Didukung & 82 & 77,4 & 24 & 22,6 & 106 & 100 & 0,802 \\
\hline Dihambat & 37 & 75,5 & 12 & 24,5 & 49 & 100 & \\
\hline
\end{tabular}

Analisis bivariat digunakan untuk melihat hubungan antara dua variabel (tabel 3) yaitu variabel dependen (sikap, norma subyektif, dan kontrol perilaku yang dirasakan) dan variabel independen (intensi masyarakat untuk berobat). Untuk membuktikan adanya hubungan antara dua variabel tersebut dilakukan uji statistik. Uji statistik dibuat dengan menggunakan uji Kendall Tau b

\section{PEMBAHASAN}

Niat seseorang memanfaatkan fasilitas kesehatan dipengaruhi oleh sikap. Sikap responden ketika sakit berobat ke Puskesmas Pembantu merupakan hal yang positif maka niat untuk berobat ke Puskesmas akan tinggi. Namun sebaliknya jika gagal memahami bahwa ketika sakit berobat ke Puskesmas maka niatnya akan rendah. Hal ini dibuktikan dengan hasil uji Kendall Tau B yaitu nilai $\rho$-Value 0,010 dengan $\alpha<0,05$ yang artinya bahwa ada pengaruh signifikan antara sikap dengan intense masyarakat untuk berobat ke Puskesmas Pembantu.

Hasil penelitian ini sejalan dengan penelitian yang dilakukan oleh Sulistiyani \& Vallen (2015) yang melakukan penelitian tentang "Analisis faktor yang mempengaruhi intensi keluarga dalam memanfaatkan pelayanan Klinik Pratama di Kecamatan Boja Kabupaten Kendal". Hasil dari penelitian tersebut menyatakan bahwa ada pengaruh secara signifikan antara sikap terhadap intensi. Menurut Ajzen dalam Pender et al. (2011), sikap merupakan evaluasi terhadap keseluruhan konsekuensi tindakan yang ingin dilakukan apakah positif atau negatif. Jika evaluasinya merupakan tindakan yang diinginkan maka sikapnya positif, namun bila tindakan itu tidak diinginkan maka sikapnya negatif.

Hasil sintesis penelitian yang telah dilakukan peneliti mengenai tingginya sikap positif yang dimiliki masyarakat disebabkan oleh meningkatnya kesadaran mengenai kesehatan dirinya tanpa dipengaruhi oleh tingkat pendidikan warga. Informasi-informasi yang diterima tentang Puskesmas juga berpengaruh terhadap sikap positif yang dimiliki oleh warga.Tingginya kesadaran mengenai kesehatan dapat juga dipengaruhi oleh kemudahan-kemudahan dalam memperoleh pelayanan kesehatan seperti adanya BPJS yang dapat digunakan untuk mendapatkan pelayanan kesehatan secara gratis. Mutu pelayanan dan fasilitas yang baik yang diberikan Puskesmas Pembantu Kotabaru dapat membantu penyebaran informasi-informasi positif mengenai Puskesmas Pembantu Kotabaru sehingga sikap warga menjadi positif ketika ingin berobat ke Puskesmas Pembantu Kotabaru.

Hubungan norma subyektif dengan intensi ditunjukkan dengan adanya dukungan keluarga ketika sakit berobat ke Puskesmas Pembantu yaitu sebesar 87,1\%, namun ada sejumlah 12,9\% responden yang menyatakan bahwa ada dukungan keluarga namun tidak memiliki niat. Responden juga menyatakan bahwa dirinya tidak mendapat dukungan dari keluarga namun ada niat untuk berobat ke Puskesmas Pembantu sebesar 61,3\% dan 38\% responden menyatakan tidak ada dukungan dari keluarga dan tidak memiliki niat. Uji statistik yang dilakukan dengan uji Kendall Tau b mendapat hasil $\rho$-Value 0,000 dengan nilai $\alpha$ $<0,05$, maka dapat disimpulkan ada hubungan yang signifikan antara norma subyektif dengan intensi warga RW 02 untuk berobat ke Puskesmas Pembantu. 
Hasil penelitian ini sejalan dengan penelitian yang dilakukan oleh (Sulistiyani \& Vallen, 2015)Sulistiyani \& Vallen(2015) yang melakukan penelitian tentang "Analisis faktor yang mempengaruhi intensi keluarga dalam memanfaatkan pelayanan Klinik Pratama di Kecamatan Boja Kabupaten Kendal". Hasil dari penelitian tersebut menyatakan bahwa ada pengaruh secara signifikan antara norma subyektif terhadap intensi. Menurut Ajzen dalam Pender et al. (2011), norma subyektif merupakan pandangan orang lain atas tindakan yang akan dilakukan, disetujui atau tidak disetujui. Dalam hal ini, orang terdekat dengan individu dapa mempengaruhi tindakan yang akan dilakukan individu.

Hasil sintensis penelitian yang dilakukan peneliti yaitu keluarga merupakan orang yang paling dekat dengan individu. Pengaruh keluarga merupakan salah satu hal yang tidak dapat dipisahkan dalam menguatkan niat untuk berobat ke Puskesmas Pembantu. Hasil penelitian dapat membuktikan bahwa besar pengaruh keluarga dalam meningkatkan niat. Sebagian besar masyarakat desa Kotabaru sadar akan pentingnya sebuah kesehatan bagi anggota keluarganya. Gangguan kesehatan dalam keluarganya dapat mempengaruhi pekerjaan dan pendapatan dalam keluarganya, selain itu adanya dukungan anggota keluarga lain, keputusan kepala keluarga juga berpengaruh terhadap keputusan untuk berobat ke Puskesmas Pembantu Kotabaru.

Hasil penelitian menunjukkan bahwa ada keluarga yang tidak mendukung namun individu memiliki niat. Hasil ini tidak dapat disimpulkan bahwa keluarga tidak pedulikan kesehatan anggota keluargnya. Kemungkinan ada pendapat lain mengenai cara memperoleh pelayanan kesehatan namun di tempat pelayanan kesehatan lain. Perlu penelitian lebih lanjut untuk membuktikan hal tersebut.

Hasil uji statistik tentang hubungan kontrol perilaku yang dirasakan dengan intensi menyatakan bahwa adanya faktor penghambat atau tidak ada factor penghambat memiliki niat tinggi yaitu masingmasing sebesar $77,4 \%$ dan $75,5 \%$. Uji statistik yang dilakukan dengan menggunakan uji Kendal Tau B menunjukkan bahwa nilai $\rho$-Value 0,802 dengan nilai $\alpha<0,05$, data tersebut menunjukkan bahwa tidak ada hubungan antara kontrol perilaku yang dirasakan dengan intensi masyarakat untuk berobat ke Puskesmas Pembantu. Jarak tempuh, transportasi, dan fasilitas layanan kesehatan di Puskesmas Pembantu tidak memberikan pengaruh pada niat responden untuk memanfaatkan fasilitas kesehatan.

Penelitian ini tidak sejalan dengan penelitian yang dilakukan oleh Sulistiyani \& Vallen (2015) yang melakukan penelitian tentang "Analisis faktor yang mempengaruhi intensi keluarga dalam memanfaatkan pelayanan Klinik Pratama di Kecamatan Boja Kabupaten Kendal". Hasil dari penelitian tersebut menyatakan bahwa ada pengaruh secara signifikan antara kontrol perilaku yang dirasakan terhadap intensi. Namun, penelitian yang dilakukan oleh Napirah et al. (2016) menunjukkan kesesuaian dengan penelitian ini dimana persepsi seseorang mengenai kualitas layanan kesehatan tidak memberikan pengaruh seseorang dalam memanfaatkan fasilitas kesehatan.

Menurut Ajzen dalam (Pender et al., 2011), persepsi individu terhadap perilaku yang akan dilakukan dengan mengukur peluang dengan adanya factor penghambat atau faktor pendukungnya.

Hasil sintesis penelitian yang dilakukan peneliti yaitu banyak hal yang memudahkan memperoleh layanan kesehatan saat ini. Hampir semua warga di lokasi tempat penelitian memiliki BPJS yang meringankan biaya layanan kesehatan yang diterima. Akses jalan, keamanan, jarak yang sebelumnya membuat intense masyarakat menurun untuk pergi ke Puskesmas Padangratu, adanya Puskemas Pembantu maka niat untuk berobat ke Puskesmas Pembantu meningkat, walaupun jika harus di rujuk tetap harus ke Puskesmas Padangratu terlebih dahulu namun cukup berpengaruh. Ketersedian kendaraan pribadi transportasi untuk dating berobat ke Puskesmas Pembantu Kotabaru juga bukan merupakan 
penghalang karena dari pengamatan rata-rata setiap rumah memiliki kendaraan bermotor. Kualitas layanan dan fasilitas yang baik menurut responden sehingga menambah rasa percaya terhadap Puskesmas Pembantu.

Kemudahan-kemudahan untuk memperoleh layanan kesehatan semakin termanfaatkan dengan baik, sehingga kontrol perilaku yang dirasakan tidak berhubungan dengan intensi.

\section{KESIMPULAN DAN SARAN}

Terdapat hubungan antara sikap dan norma subyektif dengan intensi masyarakat pada salah satu RW di Desa Kotabaru Kecamatan Padangratu Kabupaten Lampung Tengah untuk berobat Ke Puskesmas Pembantu Kotabaru. Hal ini menunjukkan, sikap yang positif terhadap pelayanan kesehatan tingkat pertama mempengaruhi niat masyarakat untuk datang berobat ke pelayanan kesehatan. Norma subyektif atau dukungan orang terdekat juga turut mempengaruhi niat masyarakat untuk datang berobat ke pelayanan kesehatan.

Puskesmas sebagai pelayanan kesehatan primer perlu mempertahankan dan meningkatkan kualitas layanannya yang diberikan sehingga kepercayaan masyarakat tetap terjaga, selain itu dukungan keluarga dan peran petugas kesehatan dalam meningkatkan kesadaran masyarakat untuk berobat ke Puskesmas sangat diperlukan

\section{REFFERENSI}

Hasmi. (2016). Metode Penelitian Kesehatan. In Media.

Kelurahan Kotabaru. (2017). Data Kependudukan Kelurahan Kota Baru Kecamatan Padang Ratu, Lampung Tengah.

Kemenkes Rl. (2014). Peraturan Menteri Kesehatan Republik Indonesia No 75 Tahun 2014 tentang Puskesmas. Kementerian Kesehatan RI. https://doi.org/10.4324/9781315853178

Masita, A., Yuniar, N., \& Lisnawaty, L. (2016). Faktor-faktor yang berhubungan dengan pemanfaatan pelayanan kesehatan pada masyarakat Desa Tanailandu di Wilayah Kerja Puskesmas Kanapa-Napa Kecamatan Mawasangka Kabupaten Buton Tengah Tahun 2015. Jurnal Ilmiah Mahasiswa Kesehatan Masyarakat Unsyiah.

Napirah, M. R., Rahman, A., \& Tony, A. (2016). Faktor-faktor yang berhubungan dengan pemanfaatan pelayanan kesehatan di Wilayah Kerja Puskesmas Tambarana Kecamatan Poso Pesisir Utara Kabupaten Poso. Jurnal Pengembangan Kota. https://doi.org/10.14710/jpk.4.1.29-39

Nasir, Abd. Murith, Abdul. deputri, M. . (2011). Buku ajar Metodologi Penelitian Kesehatan konsep Pembuatan Karya Tulis dan Thesis untuk Mahasiswa Kesehatan. In Numed. https://doi.org/10.1016/j.pdj.2014.07.001

Pender, N., Murdaugh, C., \& Parsons, M. A. (2011). Health Promotion In Nursing Practice Sixth Edition (Sixth). Pearson Education.

Polit, D., \& Beck, C. T. (2012). Nursing Research: Generating and Assessing Evidence for Nursing Practice. 9th Edition, Lippincott, Williams \& Wilkins, Philadelphia. In Wolters Kluwer

Health. https://doi.org/10.1007/s13398-014-0173-7.2

Sulistiyani, C. N., \& Vallen, N. (2015). Analisis Faktor Yang Mempengaruhi Intensi Keluarga Dalam Memanfaatkan Pelayanan Klinik Pratama Di Kecamatan Boja Kabupaten Kendal. Jurnal IImu Keperawatan Dan Kebidanan, 7, No 3, 159-169. http://182.253.197.100/e-

journal/index.php/jkk/article/view/298/322

WHO. (2017). Universal Health Coverage (UHC). http://www.who.int/news-room/factsheets/detail/universal-health-coverage-(uhc)

Wulandari, C., Ahmad, L., \& Saptaputra, S. (2016). Faktor yang berhubungan dengan pemanfaatan pelayanan kesehatan di UPTD Puskesmas Langara Kecamatan Wawonii Barat Kabupaten Konawe Kepulauan. Jurnal IImiah Mahasiswa Kesehatan Masyarakat Unsyiah. 